Keywords: Saltstone, Waste

Form, Processing

Retention: Permanent

\title{
Foam Formation in the Saltstone Production Facility (SPF): Evaluation of Sources and Mitigation
}

\author{
A.D. Cozzi
}

December 1, 2010

Savannah River National Laboratory Savannah River Nuclear Solutions, LLC Aiken, SC 29808

Prepared for the U.S. Department of Energy under contract number DE-AC09-08SR22470.

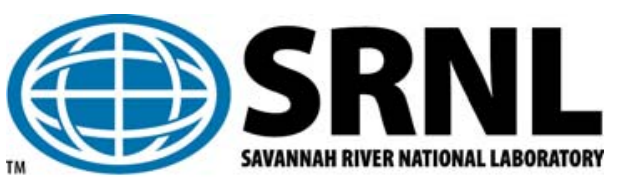


SRNL-STI-2010-00522

Revision 0

\section{DISCLAIMER}

This work was prepared under an agreement with and funded by the U.S. Government. Neither the U.S. Government or its employees, nor any of its contractors, subcontractors or their employees, makes any express or implied:

1. warranty or assumes any legal liability for the accuracy, completeness, or for the use or results of such use of any information, product, or process disclosed; or

2. representation that such use or results of such use would not infringe privately owned rights; or

3. endorsement or recommendation of any specifically identified commercial product, process, or service.

Any views and opinions of authors expressed in this work do not necessarily state or reflect those of the United States Government, or its contractors, or subcontractors.

\section{Printed in the United States of America \\ Prepared for \\ U.S. Department of Energy}




\section{REVIEWS AND APPROVALS}

AUTHORS:

A.D. Cozzi, Engineering Process Development

Date

TECHNICAL REVIEW:

M.M. Reigel, Engineering Process Development

Date

APPROVAL:

A.B. Barnes, Manager

Date

Engineering Process Development

S.L. Marra, Manager

Date

Environmental \& Chemical Process Technology Research Programs

J.E. Occhipinti, Manager

Date

Waste Solidification Engineering 


\section{EXECUTIVE SUMMARY}

The Saltstone Production Facility receives waste from Tank $50 \mathrm{H}$ for treatment. Influents into Tank $50 \mathrm{H}$ include the Effluent Treatment Project waste concentrate, $\mathrm{H}$-Canyon low activity waste and General Purpose Evaporator bottoms, Modular Caustic Side Solvent Extraction Unit decontaminated salt solution, and salt solution from the Deliquification, Dissolution and Adjust campaign. Using the Waste Characterization System (WCS), this study tracks the relative amounts of each influent into Tank $50 \mathrm{H}$, as well as the total content of Tank $50 \mathrm{H}$, in an attempt to identify the source of foaming observed in the Saltstone Production Facility hopper.

Saltstone has been using antifoam as part of routine processing with the restart of the facility in December 2006. It was determined that the maximum admix usage in the Saltstone Production Facility, both antifoam and set retarder, corresponded with the maximum concentration of $\mathrm{H}$ Canyon low activity waste in Tank $50 \mathrm{H}$.

This paper also evaluates archived salt solutions from Waste Acceptance Criteria analysis for propensity to foam and the antifoam dosage required to mitigate foaming. It was determined that Effluent Treatment Project contributed to the expansion factor (foam formation) and General Purpose Evaporator contributed to foaminess (persistence). It was also determined that undissolved solids contribute to foam persistence. It was shown that additions of Dow Corning Q2-1383a antifoam reduced both the expansion factor and foaminess of salt solutions.

The evaluation of foaming in the grout hopper during the transition from water to salt solution indicated that higher water-to-premix ratios tended to produce increased foaming. It was also shown that additions of Dow Corning Q2-1383a antifoam reduced foam formation and persistence.

Based on the testing performed in this study, several recommendations can be made to improve processing at the Saltstone Production Facility.

- Track influents as part of the WCS. The method used in this report or a similar method should be used to track the concentration of influents into Tank $50 \mathrm{H}$. The discrepancy between tank reel tape measurements and transfers should be reconciled monthly.

0 The benefit of this additional activity is to provide an additional tool to track variables in the Saltstone Facility that may effect operations such as admix demand or other fresh and cured properties.

- In future downstream effects evaluations, evaluate potential influents that are both included in the current Waste Acceptance Criteria (WAC) and new to Tank 50H.

o The added scrutiny of changes in influents will provide the Saltstone Facility an opportunity to institute or alter WAC limits to ensure safe and consistent operations.

- Perform regular formulation tests with Tank $50 \mathrm{H}$ waste to verify operating parameters and admix needs.

o A regular laboratory check of operating parameters will add assist in correlating lab prepared samples to facility production.

- Evaluate the Saltstone Production Facility operations to determine if increased water to premix during water-to-salt solution transitions is the best practice.

o A review of the rationale for instituting the high water to premix may not still be compelling and the reduced liquid flow to mixer during transition may be beneficial in reducing setbacks. 


\section{TABLE OF CONTENTS}

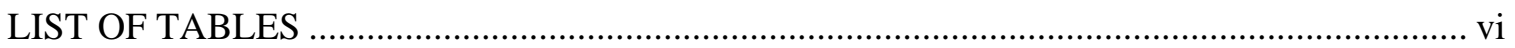

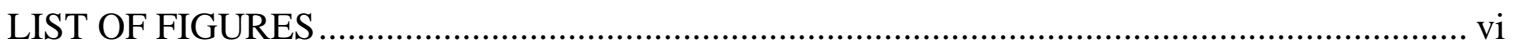

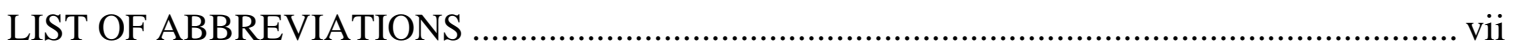

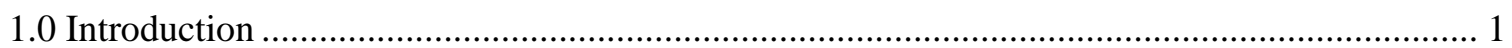

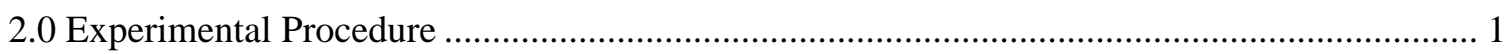

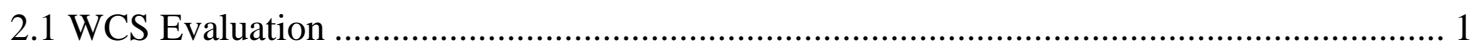

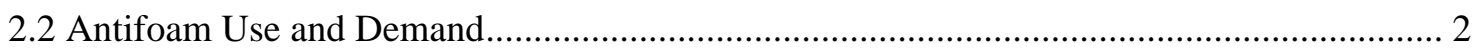

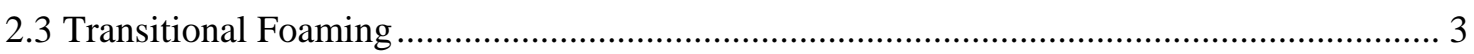

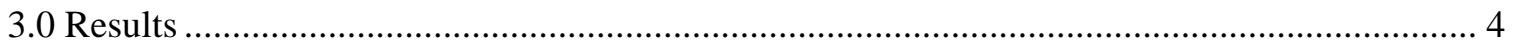

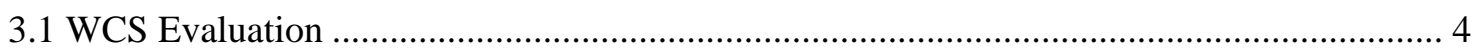

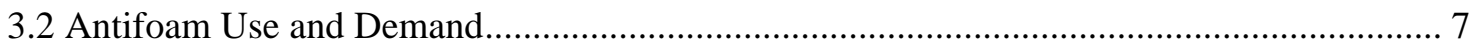

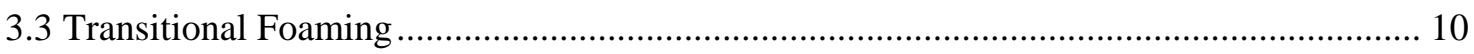

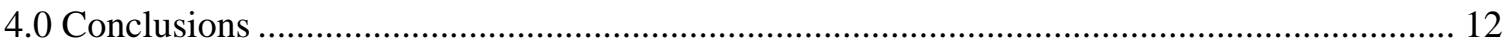

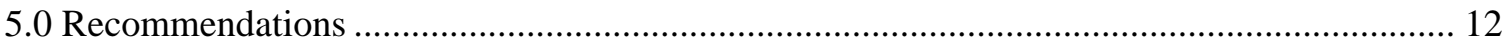

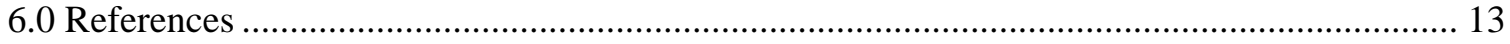


SRNL-STI-2010-00522

Revision 0

\section{LIST OF TABLES}

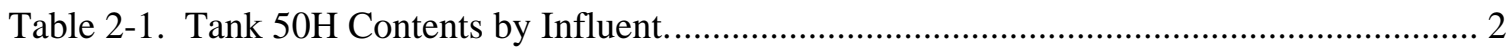

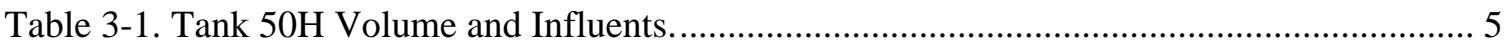

Table 3-2 Expansion Factor and Foaminess of CY07 Quarterly Samples.................................... 8

Table 3-3. Water to Salt Solution and Water-to-Premix Ratios used to Evaluate Foaming during Transition. 10

\section{LIST OF FIGURES}

Figure 2-1. Water-to-premix (W/P) ratio and solution flow rates during transition at the SPF 1/29/2009. Red lines indicate compositions tested in the lab.

Figure 3-1. Tank 50H volume and influent volume fraction.................................................... 6

Figure 3-2. Tank 50H influents of interest and admix usage during SFT processing. ................... 7

Figure 3-3 Expansion factor and foaminess in CY07 Tank 50H samples before Q2 additions..... 8

Figure 3-4 Expansion factor and foaminess as a function of influent concentration and

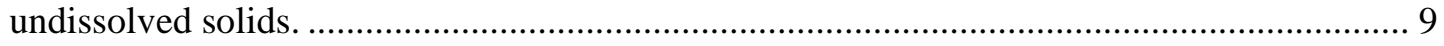

Figure 3-5 Salt solutions blended for 30 seconds. Mixes 114, 116, 115, 117, and 113,

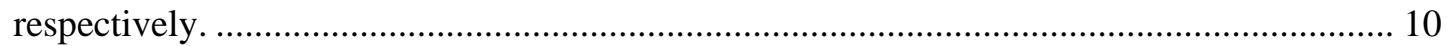

Figure 3-6 Foam formation in grout mixes blended for three minutes. Mixes 114, 116, 115, 117,

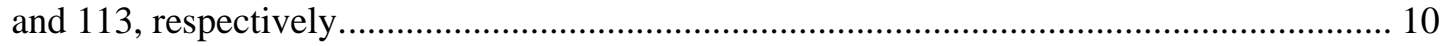

Figure 3-7 Persistence of foam in grout mixes during casting. Mixes 114, 116, 115, 117, and 113,

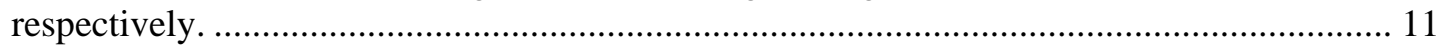

Figure 3-8 Salt solutions blended with Q2 for 30 seconds. Mixes 120, 119, and 118................ 11

Figure 3-9 Foam formation in grout mixes with Q2 blended for three minutes. Mixes 120, 119, and 118.

Figure 3-10 Persistence of foam in grout mixes with Q2 during casting. Mixes 120, 119, and 118. 


\section{LIST OF ABBREVIATIONS}

$\begin{array}{ll}\text { CA } & \text { Clear Air 100 } \\ \text { DCS } & \text { Distributed Control System } \\ \text { DDA } & \text { deliquification, dissolution, and adjustment } \\ \text { DSS } & \text { decontaminated salt solution } \\ \text { ETP } & \text { Effluent Treatment Project } \\ \text { GPE } & \text { General Purpose Evaporator } \\ \text { gPm } & \text { gallons per minute } \\ \text { IW } & \text { Inhibited water } \\ \text { LAW } & \text { low-activity waste } \\ \text { MCU } & \text { Modular Caustic Side Solvent Extraction Unit } \\ \text { Q2 } & \text { Dow Corning Q2-1383-a } \\ \text { SDF } & \text { Saltstone Disposal Facility } \\ \text { SPF } & \text { Saltstone Production Facility } \\ \text { SRNL } & \text { Savannah River National Laboratory } \\ \text { TCLP } & \text { Toxicity Characteristic Leaching Procedure } \\ \text { W/P } & \text { water-to-premix ratio } \\ \text { WAC } & \text { Waste Acceptance Criteria } \\ \text { WCP } & \text { Waste Compliance Plan } \\ \text { WCS } & \text { Waste characterization system } \\ \text { WS-E } & \text { Waste Solidification-Engineering }\end{array}$




\subsection{Introduction}

The Saltstone Production Facility (SPF) treats waste from Tank $50 \mathrm{H}$ and disposes of it in the Saltstone Disposal Facility (SDF). Tank 50H contains waste streams from H-Canyon low-activity waste $(\mathrm{LAW})^{1}$, the Effluent Treatment Project $(\mathrm{ETP})^{2}$, salt solutions from Tank Farm deliquification, dissolution, and adjustment (DDA) processing, and decontaminated salt solution from the Modular Caustic Side Solvent Extraction Unit (MCU). The waste generators issue Waste Compliance Plans (WCP) $)^{1,2}$ to demonstrate conformity to the Saltstone Waste Acceptance Criteria (WAC).

Saltstone has been using antifoam as part of routine processing for more than two years. This was initiated after Tank $50 \mathrm{H}$ began accepting transfers of H-Canyon low activity waste ${ }^{3}$. The need for antifoam continued after the campaign to process H-Canyon low activity waste stream was completed. This has led to the supposition that the small volume component of the H-Canyon low activity waste, the General Purpose Evaporator (GPE) Tank 710, may be responsible for the need to use antifoam.

Waste Solidification Engineering (WS-E) requested that Savannah River National Laboratory (SRNL) determine the primary contributors to the foaming observed in the SPF hopper ${ }^{4}$.

\subsection{Experimental Procedure}

Archived salt solutions from WAC analyses were evaluated for propensity to foam and the antifoam dosage required to mitigate foaming. The contents of Tank $50 \mathrm{H}$, based on the Waste Characterization System Version 1.5 (WCS 1.5) ${ }^{5}$, were tracked to determine the relative amounts of each influent in order to identify the source of foaming.

In the Saltstone grout hopper, foaming has been observed during transition from clean cap to saltstone production. This can trigger the high level alarm in the grout hopper. To maintain sufficient liquid flow during the transition, the water to premix ratio (W/P) goes through a step change from the production value of 0.62 to a transition value of 0.75 . MCU salt solution simulant $^{6}$ was used to evaluate the foaming detected in the SPF grout hopper during transition periods.

\subsection{WCS Evaluation}

The initial volume of waste in Tank $50 \mathrm{H}$ prior to the H-Canyon campaign was approximately 90,000 gallons. $^{7}$ The contents were approximately $76 \%$ ETP and $24 \%$ Tank $49 \mathrm{H}^{8}$. During the 2003 Tank 50 solids cleanout campaign, eight 28,000 gallon transfers of inhibited water (IW) into Tank $50 \mathrm{H}$ to mobilize tetraphenylborate solids were made. Each transfer was followed by the SPF processing 28,000 gallons to the SDF. Assuming the contents of Tank $50 \mathrm{H}$ were well mixed for each transfer, approximately five percent of the beginning Tank $50 \mathrm{H}$ contents remained. Tank $50 \mathrm{H}$ again contained approximately 90,000 gallons of material ${ }^{7}$. The 90,000 gallons in Tank $50 \mathrm{H}$ after the tetraphenylborate solids removal campaign consisted of 85,500 gallons IW and 4,500 gallons Pre 2003 Tank 50H (3,400 gallons ETP and 1,100 gallons Tank 49H). 219,000 gallons of ETP was added to this volume.

The current WCS of Tank 50H was initiated in October 2004. At that time Tank 50H contained approximately 309,000 gallons of waste. The initial composition was rebaselined by the WAC analysis of the sample collected in October $2004^{9}$. In January 2005, Tank 50H began accepting transfers of unirradiated fuel and bottoms from the H-Canyon GPE in addition to regular transfers from ETP. Laboratory testing indicated that a combination of antifoam and set retarder would be 
necessary to process salt solution with significant quantities of material from the H-Canyon influents, LAW and GPE ${ }^{10}$. Prior to the first transfer out of Tank $50 \mathrm{H}$ to the SPF in December 2006, SRNL developed a series of formulations from Tank 50H samples collected from October 2005 through September 2006 to accommodate the changes for the restart date of the SPF ${ }^{11,12,3}$. The formulation testing in these studies confirmed the need for antifoam and set retarder to meet the processing criteria.

Table 2-1 shows the approximate contents of Tank $50 \mathrm{H}$ by influent prior to the initial transfer to the SPF in December 2006. Due to in leakage from slurry pumps and the inexactness of transfer volumes, the running volume of Tank $50 \mathrm{H}$ does not reconcile with the transfers in and out of the tank.

Table 2-1. Tank 50H Contents by Influent.

\begin{tabular}{||c|c|c||}
\hline Influent & $\begin{array}{c}\text { Gallons } \\
\text { (thousands) }\end{array}$ & $\begin{array}{c}\text { Concentration } \\
\text { (vol \%) }\end{array}$ \\
\hline ETP & $3.4+219+193.4=415.8$ & 49.2 \\
\hline IW & 85.5 & 10.1 \\
\hline GPE & 39.1 & 4.63 \\
\hline H-Canyon LAW (HCAN) & 303.3 & 35.9 \\
\hline Tank 49H & 1.1 & 0.13 \\
\hline Total & 844.8 & 99.96 \\
\hline
\end{tabular}

The data in WCS1.5 is used to track the relative concentrations of the influents to Tank $50 \mathrm{H}$. Each month, WCS1.5 uses the H-Tank Farm Morning Report as a reference to input the waste transfer volumes into Tank $50 \mathrm{H}$, the source of the waste, the transfers from Tank $50 \mathrm{H}$ to the SDF, and the current Tank $50 \mathrm{H} \mathrm{level}^{5}$. Using the Tank $50 \mathrm{H}$ make up in Table $2-1$ as a starting point, the concentrations of each of the waste influents were tracked on a monthly basis. This was done by reducing the proportional amount of each influent transferred out of Tank 50H. Then, the relative concentrations were adjusted by adding the monthly influents. For example, in April 2008, WCS1.5 showed 151,666 gallons transferred from Tank 50H to the SPF, reducing the tank volume from 630,316 to 478,650 gallons. If the March 2008 concentration of GPE in Tank 50H was $0.72 \%$ (4,532 gallons), 1091 gallons of GPE (151,666 gallons x 0.72\% GPE) was transferred out during April 2008 operations, leaving 3,441 gallons of GPE in Tank 50H. WCS1.5 also indicates that 1,472 gallons of GPE was transferred into Tank 50H during April 2008 operations, raising the GPE content at the end of April 2008 to 4,914 gallons. Transfers from ETP and 512-S testing brought the April 2008 volume of Tank 50H to 494,400 gallons. The final April 2008 GPE concentration was $0.99 \%$ (4,914 gallons GPE in 494,400 gallons Tank 50H). Although the transfers in and out of Tank $50 \mathrm{H}$ in any given month are interspersed, this representation in WCS1.5 was considered adequate to track the running concentrations of the influents.

\subsection{Antifoam Use and Demand}

When the SPF restarted operations in December 2006, Clear Air 100 (100\% tributylphosphate) was specified as the antifoam. In 2008, the start of transfers of MCU decontaminated salt solution (DSS) to Tank 50H introduced an additional flammable component, Isopar (the MCU solvent), to Tank $50 \mathrm{H}$. Potential for the decomposition products of the tributylphosphate to contribute to the lower flammability limit of the facility initiated the use of an alternative antifoam. SRNL performed testing to recommend an initial dose rate of the new antifoam, Q2-1383A (Q2), in support of facility restart in January $2009^{13}$. For the testing in this report, the data collected during formulation testing with the Q2 in 2008 was reviewed. The antifoam demand recommended for processing was related to the Tank $50 \mathrm{H}$ components as calculated from the WCS. 
For salt solutions that used the Clear Air 100 antifoam (CA), archived WAC samples from CY2007 were evaluated with Q2. For comparison, archived ETP waste concentrate and GPE Tank 710 samples were also included in this study. An aliquot of each sample was transferred to a graduated glass jar with a Teflon ${ }^{\circledR}$ lid. The level was noted, the jar was lidded and the salt solution was shaken. The foam level and the time for the foam to dissipate (return to original level) were recorded. The ratio of the foam level to the original level is referred to as the expansion factor. The time for the foam to dissipate is referred to as the foaminess. Next, a solution of 1:10 Q2 to water was added to the original sample and the expansion factor and foaminess were recorded.

\subsection{Transitional Foaming}

The water flow rate, salt solution flow rate, premix delivery rate and W/P were determined for a typical start up in order to evaluate the foaming that occurs during the transition from clean cap to Saltstone. Figure 2-1 shows the liquid flow rate in gallons per minute (gpm) and W/P for the start up transition on January 29, 2009. The W/P was calculated from the weight percent solids of the salt solution. This was done by fitting the density versus weight percent solids of the 1Q09 WAC sample $^{14}$ and an SRNL MCU DSS simulant with similar hydroxide and nitrate concentrations. The specific gravity of the SFT from PI Processbook data collected January 29, 2009 from the SPF Distributed Control System DCS) was used to determine the weight percent solids of the SFT. The blended water/SFT composite weight percent solids for each PI sample throughout the transition were calculated.

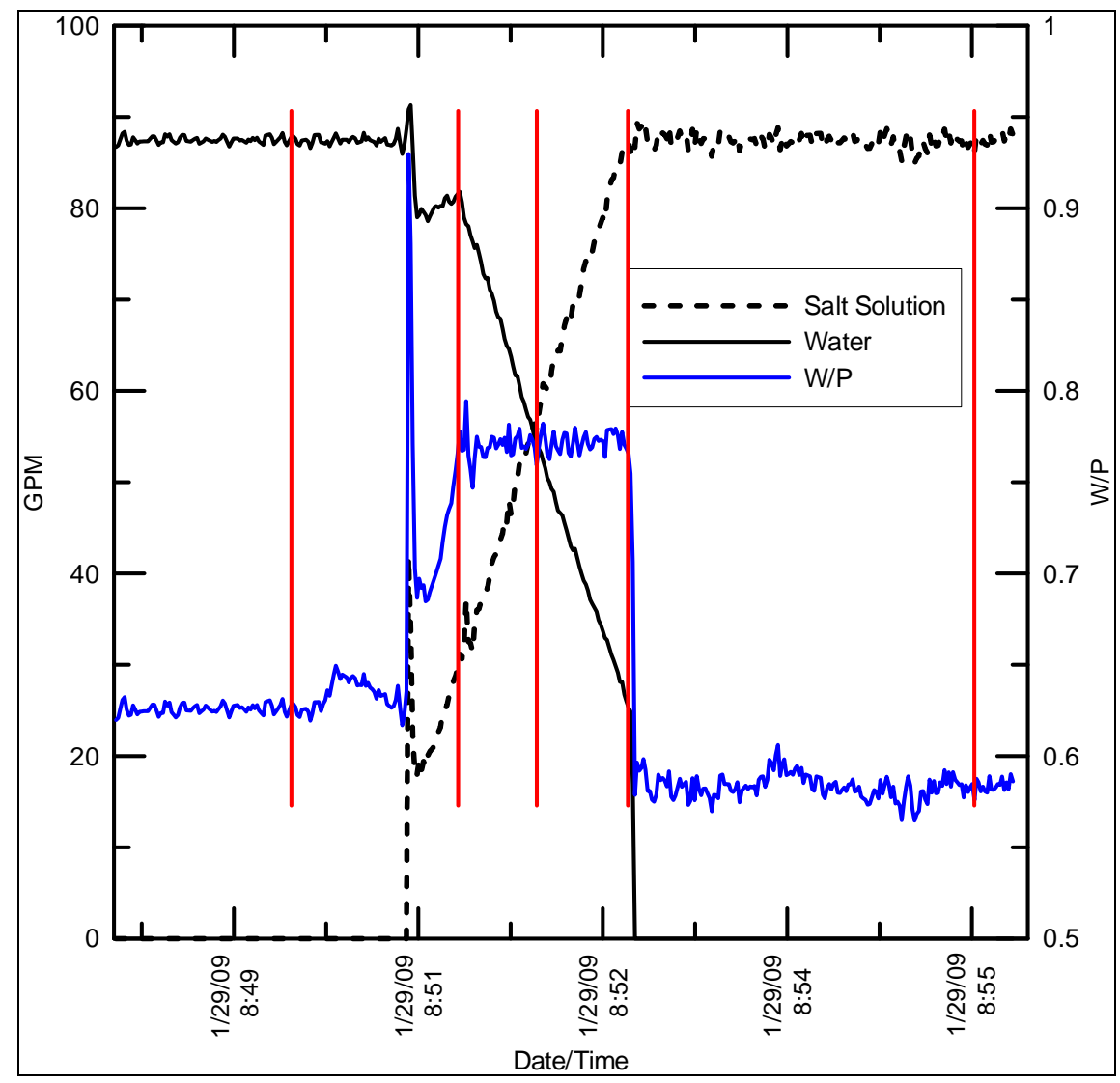

Figure 2-1. Water-to-premix (W/P) ratio and solution flow rates during transition at the SPF 1/29/2009. Red lines indicate compositions tested in the lab. 
To emulate this behavior under static conditions, mixes were made using the solution compositions and the W/P represented by the red vertical lines in Figure 2-1. The solution was mixed in a blender to determine if the solution alone would result in sustained foam. Then, the premix, a blend of cement, blast furnace slag, and class F fly ash in a ratio of 10/45/45, was added and the slurry was mixed for two minutes and evaluated for foaming. After mixing, the slurry was transferred into a 2 x 4 cylinder and archived. The three tests with the highest salt content (from the middle of the transition period to full salt operations) were then repeated with Q2 antifoam. The Q2 was added to the salt solution at the 1Q2009 dose rate of 0.9 gallons admix per ton of premix.

\subsection{Results}

\subsection{WCS Evaluation}

Table 3-1 is the calculated running inventory of influents in Tank $50 \mathrm{H}$ by volume percent based on data in WCS1.5 calculated as described in Section 2.1. The determination of the initial content of Tank $50 \mathrm{H}$ is described in Section 2.1. The Tank $49 \mathrm{H}$ material in the initial Tank $50 \mathrm{H}$ heel was wash water from the salt decontamination demonstration ${ }^{15}$. Tank $49 \mathrm{H}$ additions to Tank $50 \mathrm{H}$ after WCS1.5 began tracking influents in 2004 was dissolved salt cake from Tank $41 \mathrm{H}^{16}$ blended with inhibited water. The volume of Tank $50 \mathrm{H}$ is taken directly from WCS1.5. The admix dose rates in the table are on a weight percent premix basis. The admix dose rates were initially collected from recommendations in formulation reports for Salt Batch $0^{11,12,3}$. The change in admix dose rate from an October 2005 sample to SPF start up in December 2006 was due to a change in recommended admix doses from testing on a subsequent Tank 50H sample collected in May 2006. After restart of the SPF in December of 2006, admix additions were provided by WS-E for preparation of the quarterly samples prepared by SRNL for Toxicity Characteristic Leaching Procedure (TCLP) testing. These admix dose rates were the values input into Table 3-1. Figure 3-1 shows the data from Table 3-1 in graphical form. The volume fraction of each of the influents is shown on the left $\mathrm{Y}$-axis and the running volume of Tank $50 \mathrm{H}$ is shown on the right $\mathrm{Y}$-axis in gallons. 
Table 3-1. Tank 50H Volume and Influents.

\begin{tabular}{|c|c|c|c|c|c|c|c|c|c|c|c|}
\hline Date & $\begin{array}{l}\begin{array}{l}\text { Volume } \\
\text { (gallons) }\end{array} \\
\end{array}$ & $\begin{array}{c}\text { ETP } \\
(\text { vol \%) }\end{array}$ & $\begin{array}{l}\text { HCAN } \\
\text { (vol \%) }\end{array}$ & $\begin{array}{c}\text { GPE } \\
\text { (vol \%) }\end{array}$ & \begin{tabular}{|c|}
49 and 23 \\
$($ vol \%)
\end{tabular} & $\begin{array}{l}\text { Caustic } \\
\text { (vol \%) }\end{array}$ & $\begin{array}{c}\text { IW } \\
\text { (vol \%) }\end{array}$ & $\begin{array}{c}\text { MCU } \\
\text { (vol \%) }\end{array}$ & $\begin{array}{c}\text { D17 } \\
\text { (wt \%) }\end{array}$ & $\begin{array}{c}\text { CA } \\
\text { (wt \%) }\end{array}$ & $\begin{array}{c}\text { Q2 } \\
\text { (wt \%) }\end{array}$ \\
\hline 09/31/04 & 309231 & 71.92 & 0.00 & 0.00 & 0.36 & 0.00 & 27.65 & 0.00 & -- & -- & -- \\
\hline $10 / 31 / 04$ & 312137 & 72.18 & 0.00 & 0.00 & 0.35 & 0.00 & 27.39 & 0.00 & -- & -- & -- \\
\hline $11 / 30 / 04$ & 321743 & 73.01 & 0.00 & 0.00 & 0.34 & 0.00 & 26.57 & 0.00 & -- & -- & -- \\
\hline $12 / 31 / 04$ & 329989 & 73.69 & 0.00 & 0.00 & 0.33 & 0.00 & 25.91 & 0.00 & -- & -- & -- \\
\hline $01 / 31 / 05$ & 351879 & 74.28 & 1.04 & 0.00 & 0.31 & 0.00 & 24.30 & 0.00 & -- & -- & -- \\
\hline $02 / 28 / 05$ & 381673 & 72.07 & 5.18 & 0.00 & 0.29 & 0.00 & 22.40 & 0.00 & -- & -- & -- \\
\hline $03 / 31 / 05$ & 422453 & 69.85 & 9.28 & 0.32 & 0.26 & 0.00 & 20.24 & 0.00 & -- & -- & -- \\
\hline $04 / 30 / 05$ & 433699 & 69.68 & 9.99 & 0.31 & 0.25 & 0.00 & 19.71 & 0.00 & -- & -- & -- \\
\hline $05 / 31 / 05$ & 467286 & 65.91 & 14.65 & 0.87 & 0.24 & 0.00 & 18.30 & 0.00 & -- & -- & -- \\
\hline $06 / 30 / 05$ & 499732 & 63.07 & 18.36 & 1.19 & 0.22 & 0.00 & 17.11 & 0.00 & -- & -- & -- \\
\hline $07 / 31 / 05$ & 506907 & 63.60 & 18.10 & 1.17 & 0.22 & 0.00 & 16.87 & 0.00 & -- & -- & -- \\
\hline $08 / 31 / 05$ & 516159 & 63.57 & 18.15 & 1.45 & 0.21 & 0.00 & 16.56 & 0.00 & -- & -- & -- \\
\hline 09/30/05 & 529376 & 63.08 & 18.76 & 1.75 & 0.21 & 0.00 & 16.15 & 0.00 & -- & -- & -- \\
\hline $10 / 31 / 05$ & 545475 & 62.81 & 19.34 & 1.93 & 0.20 & 0.00 & 15.67 & 0.00 & 0.18 & 0.13 & 0.00 \\
\hline $11 / 30 / 05$ & 568625 & 61.28 & 21.46 & 1.99 & 0.19 & 0.00 & 15.04 & 0.00 & 0.18 & 0.13 & 0.00 \\
\hline $12 / 31 / 05$ & 589129 & 60.13 & 22.95 & 2.18 & 0.19 & 0.00 & 14.51 & 0.00 & 0.18 & 0.13 & 0.00 \\
\hline $01 / 31 / 06$ & 636560 & 57.71 & 26.31 & 2.34 & 0.17 & 0.00 & 13.43 & 0.00 & 0.18 & 0.13 & 0.00 \\
\hline $02 / 28 / 06$ & 658491 & 56.67 & 27.65 & 2.49 & 0.17 & 0.00 & 12.98 & 0.00 & 0.18 & 0.13 & 0.00 \\
\hline 03/31/06 & 682986 & 55.59 & 29.00 & 2.70 & 0.16 & 0.00 & 12.52 & 0.00 & 0.18 & 0.13 & 0.00 \\
\hline $04 / 30 / 06$ & 705333 & 54.23 & 30.74 & 2.72 & 0.16 & 0.00 & 12.12 & 0.00 & 0.18 & 0.13 & 0.00 \\
\hline $05 / 31 / 06$ & 729363 & 52.64 & 32.22 & 3.24 & 0.15 & 0.00 & 11.72 & 0.00 & 0.27 & 0.13 & 0.00 \\
\hline 06/30/06 & 740310 & 50.89 & 34.33 & 3.40 & 0.14 & 0.00 & 11.20 & 0.00 & 0.27 & 0.13 & 0.00 \\
\hline $07 / 31 / 06$ & 774262 & 49.53 & 36.05 & 3.55 & 0.14 & 0.00 & 10.71 & 0.00 & 0.27 & 0.13 & 0.00 \\
\hline $08 / 31 / 06$ & 806496 & 48.87 & 36.73 & 3.96 & 0.13 & 0.00 & 10.28 & 0.00 & 0.27 & 0.13 & 0.00 \\
\hline $09 / 30 / 06$ & 818782 & 49.15 & 36.35 & 4.16 & 0.13 & 0.00 & 10.18 & 0.00 & 0.27 & 0.13 & 0.00 \\
\hline 10/31/06 & 821800 & 49.25 & 36.22 & 4.23 & 0.13 & 0.00 & 10.14 & 0.00 & 0.27 & 0.13 & 0.00 \\
\hline $11 / 30 / 06$ & 826939 & 49.11 & 35.99 & 4.66 & 0.13 & 0.00 & 10.08 & 0.00 & 0.27 & 0.13 & 0.00 \\
\hline $12 / 31 / 06$ & 766564 & 49.14 & 35.78 & 4.91 & 0.13 & 0.00 & 10.02 & 0.00 & 0.27 & 0.13 & 0.00 \\
\hline $01 / 31 / 07$ & 787329 & 49.67 & 34.79 & 5.65 & 0.13 & 0.00 & 9.74 & 0.00 & 0.27 & 0.13 & 0.00 \\
\hline $02 / 28 / 07$ & 713655 & 49.71 & 34.06 & 5.64 & 1.03 & 0.00 & 9.54 & 0.00 & 0.27 & 0.14 & 0.00 \\
\hline $03 / 31 / 07$ & 623733 & 49.97 & 33.38 & 5.77 & 1.51 & 0.00 & 9.34 & 0.00 & 0.27 & 0.14 & 0.00 \\
\hline $04 / 30 / 07$ & 632011 & 50.51 & 32.94 & 5.82 & 1.49 & 0.00 & 9.22 & 0.00 & 0.27 & 0.14 & 0.00 \\
\hline $05 / 31 / 07$ & 633916 & 50.54 & 32.84 & 5.92 & 1.49 & 0.00 & 9.19 & 0.00 & 0.27 & 0.14 & 0.00 \\
\hline $06 / 30 / 07$ & 643296 & 50.62 & 32.65 & 6.09 & 1.48 & 0.00 & 9.14 & 0.00 & 0.27 & 0.14 & 0.00 \\
\hline $07 / 31 / 07$ & 657251 & 51.56 & 31.95 & 6.07 & 1.45 & 0.00 & 8.94 & 0.00 & 0.27 & 0.14 & 0.00 \\
\hline $08 / 31 / 07$ & 663771 & 51.15 & 31.64 & 6.89 & 1.43 & 0.00 & 8.86 & 0.00 & 0.27 & 0.14 & 0.00 \\
\hline $09 / 30 / 07$ & 797218 & 43.14 & 26.34 & 5.74 & 15.78 & 1.60 & 7.37 & 0.00 & 0.27 & 0.07 & 0.00 \\
\hline 10/31/07 & 624595 & 42.67 & 25.83 & 5.62 & 15.48 & 1.57 & 8.81 & 0.00 & 0.27 & 0.07 & 0.00 \\
\hline $11 / 30 / 07$ & 317383 & 41.77 & 25.13 & 5.47 & 15.05 & 1.52 & 11.04 & 0.00 & 0.19 & 0.07 & 0.00 \\
\hline $12 / 31 / 07$ & 501236 & 7.12 & 3.28 & 0.71 & 79.63 & 0.20 & 9.06 & 0.00 & 0.19 & 0.07 & 0.00 \\
\hline 01/31/08 & 956516 & 4.81 & 1.72 & 0.37 & 85.50 & 0.10 & 7.49 & 0.00 & 0.19 & 0.07 & 0.00 \\
\hline $02 / 29 / 08$ & 884970 & 6.54 & 1.65 & 0.36 & 82.13 & 0.10 & 9.22 & 0.00 & 0.19 & 0.07 & 0.00 \\
\hline $03 / 31 / 08$ & 630316 & 8.03 & 1.62 & 0.73 & 80.49 & 0.10 & 9.04 & 0.00 & 0.08 & 0.10 & 0.00 \\
\hline $04 / 30 / 08$ & 494400 & 9.01 & 1.56 & 1.00 & 77.92 & 0.09 & 10.40 & 0.00 & 0.08 & 0.10 & 0.00 \\
\hline $05 / 31 / 08$ & 517095 & 10.13 & 1.50 & 1.10 & 74.50 & 0.09 & 9.95 & 2.74 & 0.08 & 0.10 & 0.00 \\
\hline $06 / 30 / 08$ & 560568 & 10.98 & 1.43 & 1.45 & 71.19 & 0.09 & 9.50 & 5.36 & 0.08 & 0.10 & 0.00 \\
\hline $07 / 31 / 08$ & 646586 & 11.42 & 1.34 & 1.60 & 67.24 & 0.08 & 8.91 & 9.41 & 0.08 & 0.10 & 0.00 \\
\hline $08 / 31 / 08$ & 742989 & 10.71 & 1.17 & 1.88 & 60.46 & 0.07 & 7.75 & 17.96 & 0.08 & 0.10 & 0.00 \\
\hline $09 / 30 / 08$ & 789835 & 11.22 & 1.10 & 1.96 & 60.31 & 0.07 & 7.29 & 16.89 & 0.08 & 0.10 & 0.00 \\
\hline $10 / 31 / 08$ & 796843 & 11.48 & 1.07 & 2.13 & 60.58 & 0.06 & 7.10 & 16.45 & 0.08 & 0.00 & 0.03 \\
\hline $11 / 30 / 08$ & 794473 & 11.88 & 1.05 & 2.85 & 59.79 & 0.06 & 7.01 & 16.24 & 0.08 & 0.00 & 0.03 \\
\hline $12 / 31 / 08$ & 819335 & 13.20 & 1.70 & 3.44 & 57.98 & 0.06 & 6.80 & 15.75 & 0.08 & 0.00 & 0.03 \\
\hline $01 / 31 / 09$ & 543553 & 13.40 & 2.34 & 4.42 & 55.32 & 0.06 & 6.49 & 16.95 & 0.08 & 0.00 & 0.03 \\
\hline $02 / 28 / 09$ & 581611 & 13.26 & 3.85 & 4.56 & 51.70 & 0.06 & 6.06 & 19.55 & 0.08 & 0.00 & 0.03 \\
\hline $03 / 31 / 09$ & 615313 & 13.98 & 4.75 & 4.32 & 45.15 & 0.05 & 5.29 & 25.62 & 0.13 & 0.00 & 0.02 \\
\hline $04 / 30 / 09$ & 600422 & 9.11 & 2.88 & 2.71 & 57.07 & 0.03 & 2.80 & 24.96 & 0.13 & 0.00 & 0.02 \\
\hline $05 / 31 / 09$ & 505472 & 20.26 & 4.41 & 3.48 & 67.79 & 0.03 & 3.33 & 40.69 & 0.13 & 0.00 & 0.02 \\
\hline
\end{tabular}




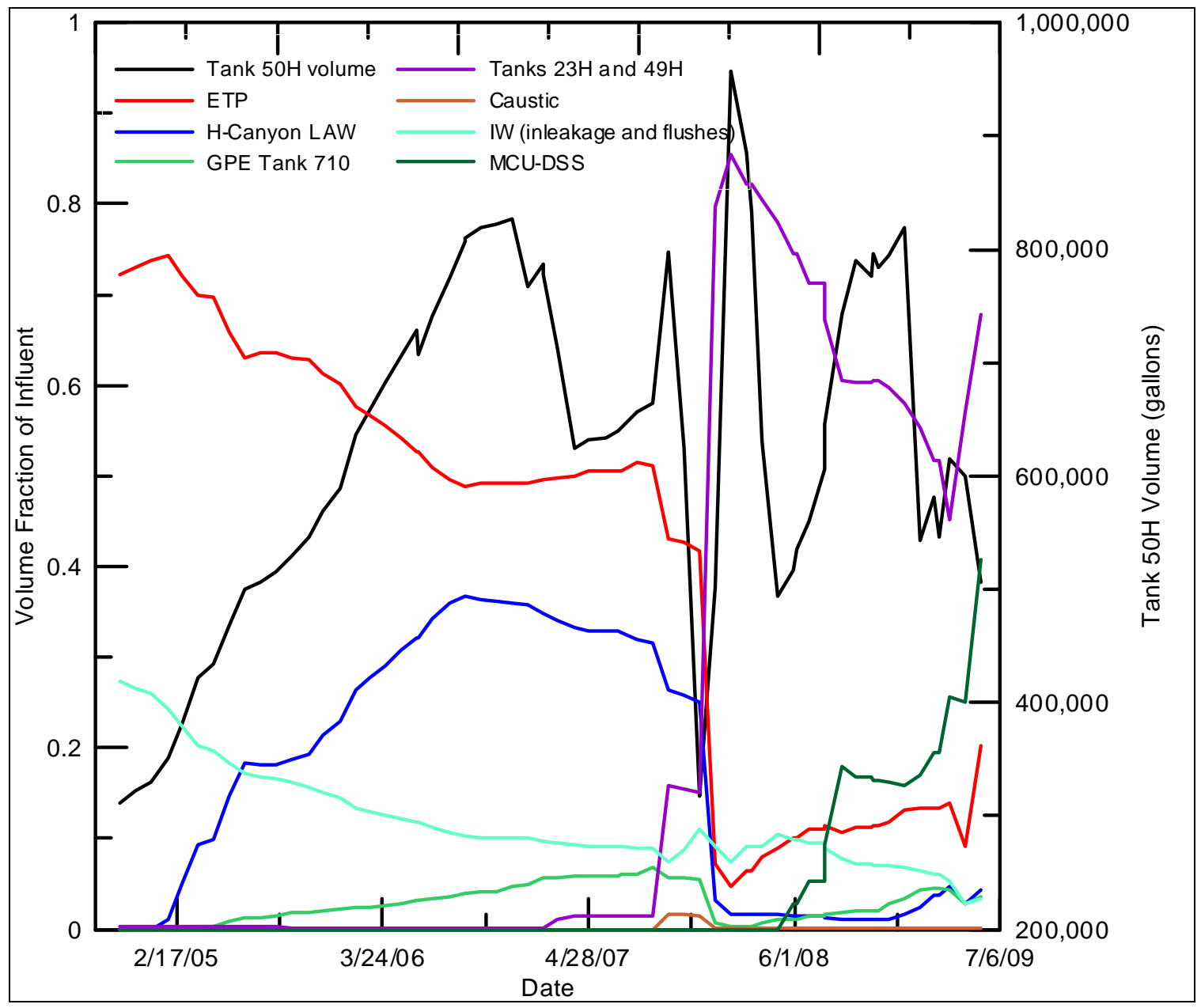

Figure 3-1. Tank 50H volume and influent volume fraction.

Figure 3-2 shows the fraction of influents with water and caustic not displayed. The admix use in weight percent premix is plotted on the second Y-axis. In Figure 3-1, the initial makeup of Tank $50 \mathrm{H}$ is primarily ETP and water. In 2005, H-Canyon initiated transfer of LAW to Tank 50H. The initial admix dosage recommended in Reference 12 introduces the need for antifoam and set retarder for initial Batch 0 processing. The need for antifoam and set retarder for processing $\mathrm{H}-$ Canyon waste in the SPF was determined during a downstream effect study ${ }^{10}$. Significant additions to Tank $50 \mathrm{H}$ during delay in SPF start up prompted a second formulation study in September 2006. This study recommended an increase in set retarder to meet the processing property goals of the study. The increase in the Daratard 17 set retarder occurred in May 2006 and is illustrated by the dashed green line in Figure 3-2. From the initiation of WCS1.5 until SPF startup in December 2006, the volume of Tank $50 \mathrm{H}$ steadily increased. However, as can be seen in Figure 3-2, after the introduction of H-Canyon wastes, the relative proportion of ETP was reduced as the H-Canyon LAW and GPE were added at a greater rate than ETP. As new waste streams were introduced with the onset of DDA (Tanks 23H and 49H) and MCU (DSS), formulation studies recommended a reduction in the antifoam (CA $)^{17}$ and a subsequent reduction in the set retarder ${ }^{18}$. To support the Tank $23 \mathrm{H}$ and Tank $49 \mathrm{H}$ additions to Tank $50 \mathrm{H}$, a formulation study in January 2008 recommended further reduction of the antifoam requirements ${ }^{19}$. At the time, the facility was unable to consistently deliver the recommended dosage and instead added the minimum antifoam dose that could be reliably delivered by the existing equipment. 


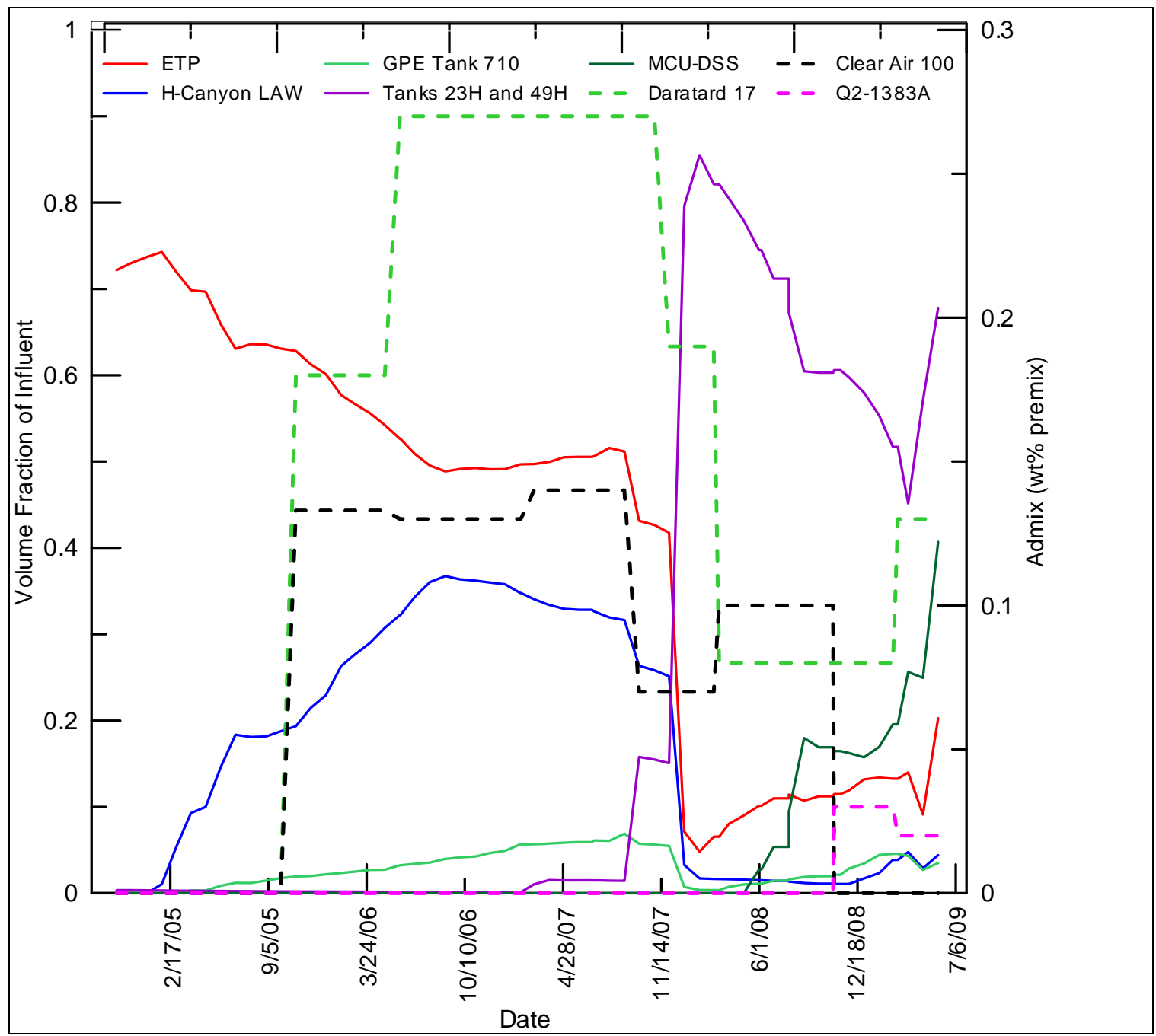

Figure 3-2. Tank 50H influents of interest and admix usage during SFT processing.

\subsection{Antifoam Use and Demand}

The expansion factor and foaminess was determined for each of the CY07 quarterly samples as well as samples of GPE and ETP. The 2Q07 sample was tested as the slurry and supernate only. The effect of Q2 antifoam additions on these samples was also determined. Table 3-2 is the foam height, expansion factor, and foaminess for salt solution samples as received and after being dosed with Q2. In Table 3-1, the concentration of the majority of influents remains constant through CY07. Through CY07, the concentration of the H-Canyon LAW decreased and the concentration of the DDA influent increased. These changes were most prevalent in the fourth quarter. When expansion factor and foaminess of the samples in Table 3-2 are compared with the influents in Table 3-1, there does not appear to be a relationship between influent concentration, expansion factor, or foaminess. However, Tank $50 \mathrm{H}$ operations were altered after Revision 7 of the WAC was approved in February $2007^{20}$. In Revision 7, the total alpha limit was raised to $2.5 \mathrm{E}+05 \mathrm{pCi} / \mathrm{mL}$. The increase in allowable alpha enabled the change in elevation of the Tank $50 \mathrm{H}$ transfer pump from a height of sixty inches to three inches. In addition, the slurry pumps could be operated during transfers to the SPF. This change resulted in a greater amount of solids transferred to the SPF. This was accompanied by the change in the conditions with which the quarterly WAC sample was collected, with slurry pumps operating. 
Table 3-2 Expansion Factor and Foaminess of CY07 Quarterly Samples.

\begin{tabular}{|c|c|c|c|c|c|c|}
\hline CY07 & $\begin{array}{c}\text { Wt } \% \\
\text { undissolved } \\
\text { solids } \\
\end{array}$ & $\begin{array}{c}\text { Initial } \\
\text { Level } \\
\text { (arb units) } \\
\end{array}$ & $\begin{array}{c}\text { Foam } \\
\text { Height } \\
\text { (arb units) } \\
\end{array}$ & $\begin{array}{c}\text { Expansion } \\
\text { Factor } \\
\end{array}$ & $\begin{array}{c}\text { Foaminess } \\
\text { (s) }\end{array}$ & $\begin{array}{c}\text { Q2 } \\
\text { Dose } \\
(0.02 \text { g) } \\
\end{array}$ \\
\hline \multirow{2}{*}{ 1Q } & \multirow{2}{*}{$0.01^{21}$} & 2 & 2.5 & 1.25 & 50 & 0 \\
\hline & & 2 & 2 & 1 & 0 & 1 \\
\hline \multirow{2}{*}{$2 Q$} & \multirow{2}{*}{$0.60^{22}$} & 2 & 3 & 1.5 & 10 & 0 \\
\hline & & 2 & 2 & 1 & 0 & 1 \\
\hline \multirow{2}{*}{$\begin{array}{c}2 \mathrm{Q} \\
\text { supernate }\end{array}$} & \multirow{2}{*}{0} & 2 & 2.5 & 1.25 & 6 & 0 \\
\hline & & 2 & 2 & 1 & 0 & 1 \\
\hline \multirow{3}{*}{$3 Q$} & \multirow{3}{*}{$0.12^{23}$} & 2 & 2.6 & 1.3 & 15 & 0 \\
\hline & & 2 & 2.2 & 1.1 & 2 & 1 \\
\hline & & 2 & 2 & 1 & 0 & 2 \\
\hline \multirow{2}{*}{$4 Q$} & \multirow{2}{*}{$0.45^{24}$} & 2 & 2.5 & 1.25 & 10 & 0 \\
\hline & & 2 & 2 & 1 & 0 & 1 \\
\hline \multirow{3}{*}{ ETP } & \multirow{3}{*}{$\begin{array}{c}\text { not } \\
\text { measured }\end{array}$} & 2 & 2.8 & 1.4 & 5 & 0 \\
\hline & & 2 & 2.4 & 1.2 & 5 & 1 \\
\hline & & 2 & 2 & 1 & 0 & 2 \\
\hline \multirow{2}{*}{ GPE } & \multirow{2}{*}{$\begin{array}{c}\text { not } \\
\text { measured }\end{array}$} & 2 & 2.2 & 1.1 & 30 & 0 \\
\hline & & 2 & 2 & 1 & 0 & 1 \\
\hline
\end{tabular}

In Figure 3-3, the expansion factor and foaminess are plotted as a function of date for the four quarters of CY07.

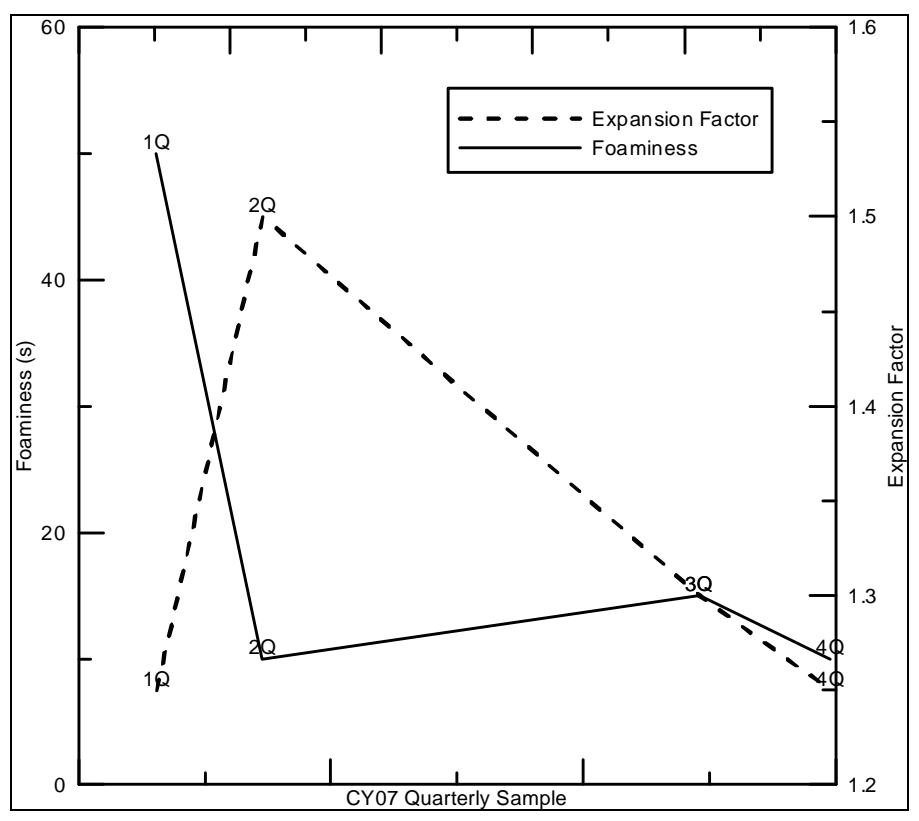

Figure 3-3 Expansion factor and foaminess in CY07 Tank 50H samples before Q2 additions. 
The concentrations of all of the influents in Tank $50 \mathrm{H}$ did not change monotonically during CY07. The expansion factor and foaminess were then plotted against the concentration of the GPE, HCanyon LAW and Tanks 23/49 (Figure 3-4). The expansion factor and foaminess were also plotted against the undissolved solids measured in the quarterly WAC samples.
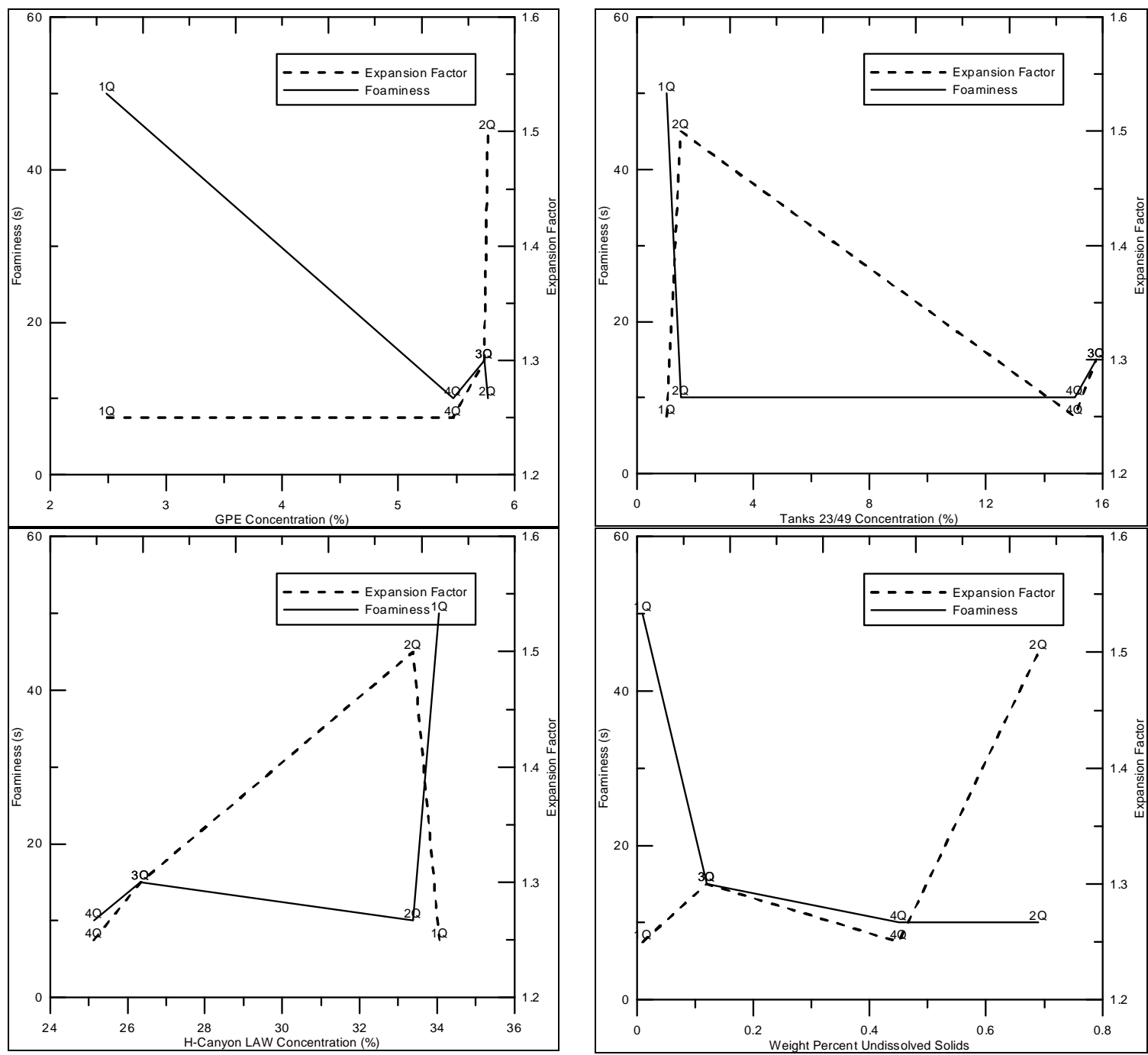

Figure 3-4 Expansion factor and foaminess as a function of influent concentration and undissolved solids.

The only plot exhibiting a trend is the decrease in foaminess with increasing undissolved solids. Further examination of the plots shows no trend with any influent. However, it does appear that the expansion factor increases with increased undissolved solids. This trend has been demonstrated in various other systems ${ }^{25,26}$. In all cases, small doses of Q2 were able to reduce the expansion and foaminess (sustainability) of the foam. Even without antifoam additions the foams created in the salt solution were unstable and considered evanescent. 


\subsection{Transitional Foaming}

The eight mixes prepared in Section 2.3 are shown in Table 3-3 and include the calculated weight percent solids used to determine the $\mathrm{W} / \mathrm{P}$ ratios.

Table 3-3. Water to Salt Solution and Water-to-Premix Ratios used to Evaluate Foaming during Transition.

\begin{tabular}{|c|c|c|c|c||}
\hline \hline Mix Number & $\begin{array}{c}\text { Water: Salt Solution } \\
\text { (MCU) }\end{array}$ & $\begin{array}{c}\text { Weight Percent Solids } \\
\text { (calculated) }\end{array}$ & W/P & Q2 \\
\hline 114 & $100: 0$ & 0 & 0.60 & no \\
\hline 116 & $71: 29$ & 9.90 & 0.75 & no \\
\hline 115 & $50: 50$ & 16.3 & 0.75 & no \\
\hline 117 & $22: 78$ & 23.9 & 0.75 & no \\
\hline 113 & $0: 100$ & 29.3 & 0.60 & no \\
\hline 120 & $71: 29$ & 9.90 & 0.75 & yes \\
\hline 119 & $50: 50$ & 16.3 & 0.75 & yes \\
\hline 118 & $0: 100$ & 29.3 & 0.60 & yes \\
\hline
\end{tabular}

Figure 3-5 is the simulant salt solutions blended for thirty seconds. All of the solutions containing dissolved salts foamed during blending. The foam created during blending was evanescent and dissipated rapidly. After the foam had dissipated, the appropriate amount of premix was added to obtain the desired W/P and the mix was blended for approximately one minute. The mix was examined to ensure the premix was incorporated and mixed for an additional two minutes. After mixing, the mixes were inspected for foam (Figure 3-6).
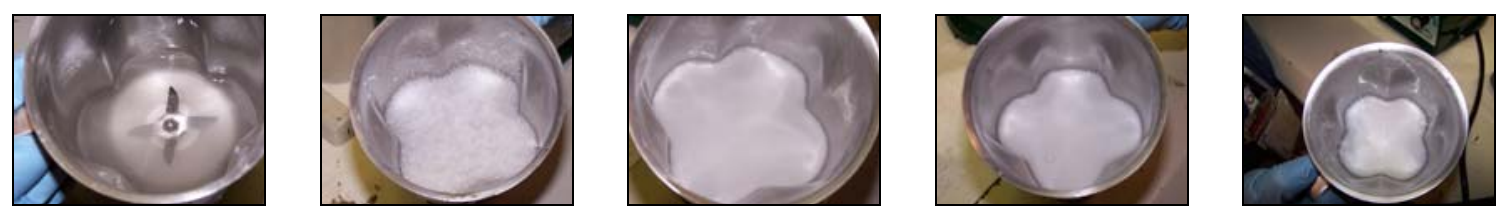

Figure 3-5 Salt solutions blended for 30 seconds. Mixes 114, 116, 115, 117, and 113, respectively.
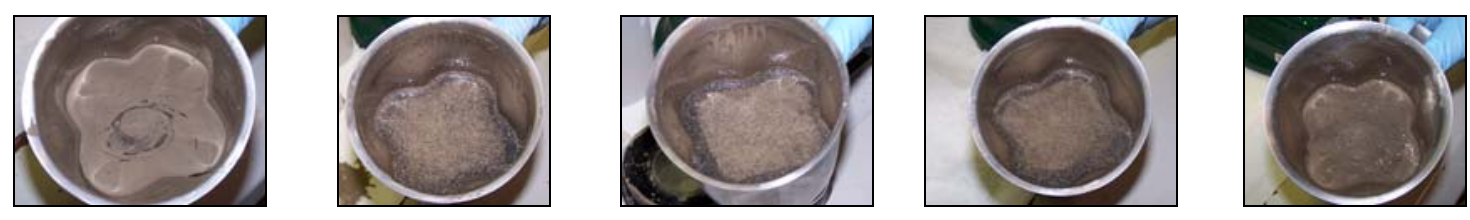

Figure 3-6 Foam formation in grout mixes blended for three minutes. Mixes 114, 116, 115, 117, and 113, respectively.

As can be seen in Figure 3-6, the clean cap formulation (mix 114) was the only mix to not develop foam. The three transition blends at the higher W/P all exhibited the most foam. Figure 3-7 shows the persistence of the foams through the casting of the mixes into molds. 

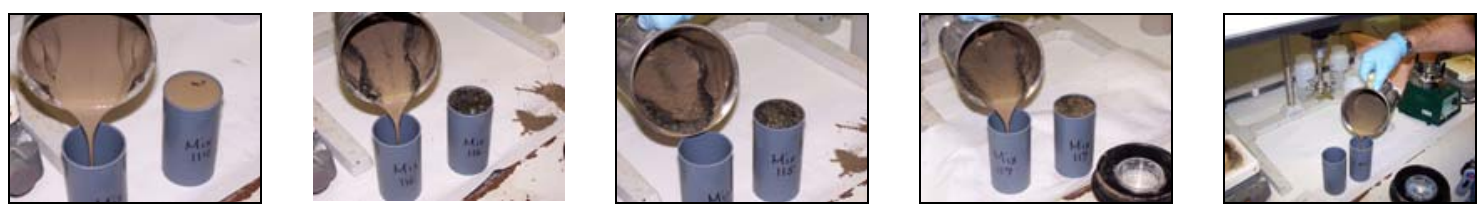

Figure 3-7 Persistence of foam in grout mixes during casting. Mixes 114, 116, 115, 117, and 113, respectively.

Three mixes (119, 120, and 118) prepared with Q2 antifoam were prepared and evaluated in the same manner as the previous mixes. Figure 3-8 shows the salt solutions mixed for thirty seconds. Although foam was generated, in each mix the foam dissipated quickly.
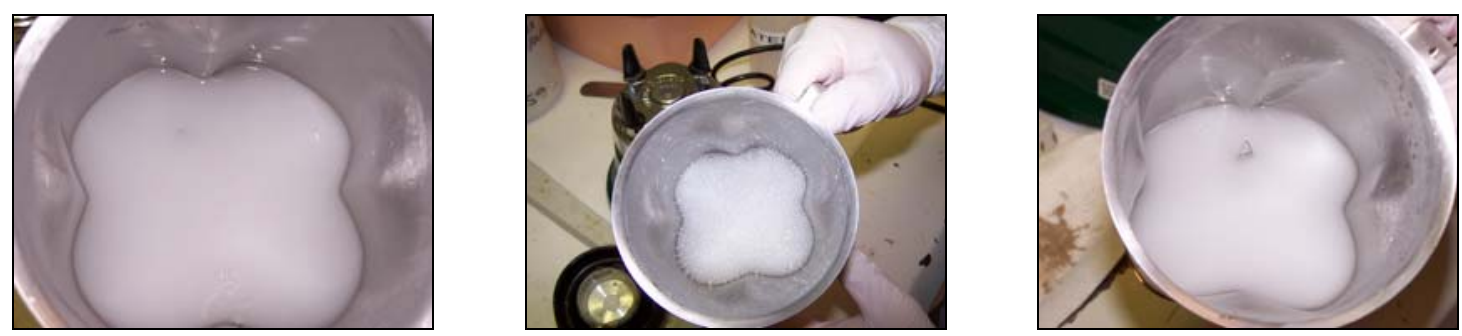

Figure 3-8 Salt solutions blended with Q2 for 30 seconds. Mixes 120, 119, and 118.

Premix was added to the salt solutions and blended for three minutes (Figure 3-9). Each of the mixes developed foam, decreasing in amount with increasing salt content. It also appears that the mixes with a greater W/P developed more foam than the mix with a W/P of 0.60 .
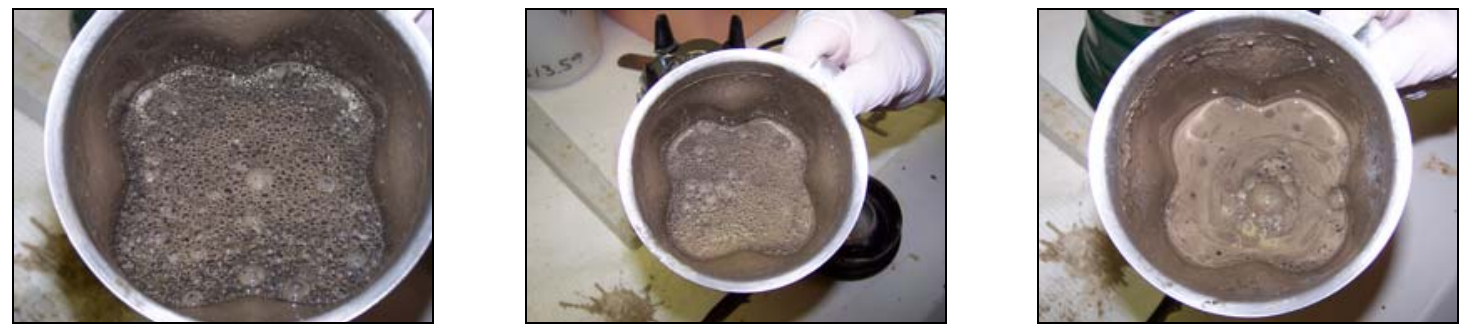

Figure 3-9 Foam formation in grout mixes with Q2 blended for three minutes. Mixes 120, 119, and 118.

The mixes were cast in to molds (Figure 3-10) to evaluate the persistence of the foam. The Q2 antifoam noticeably reduced both the expansion factor and the foaminess of the mixes. This reduction was more evident in the mix with the $\mathrm{W} / \mathrm{P}$ of 0.60 .

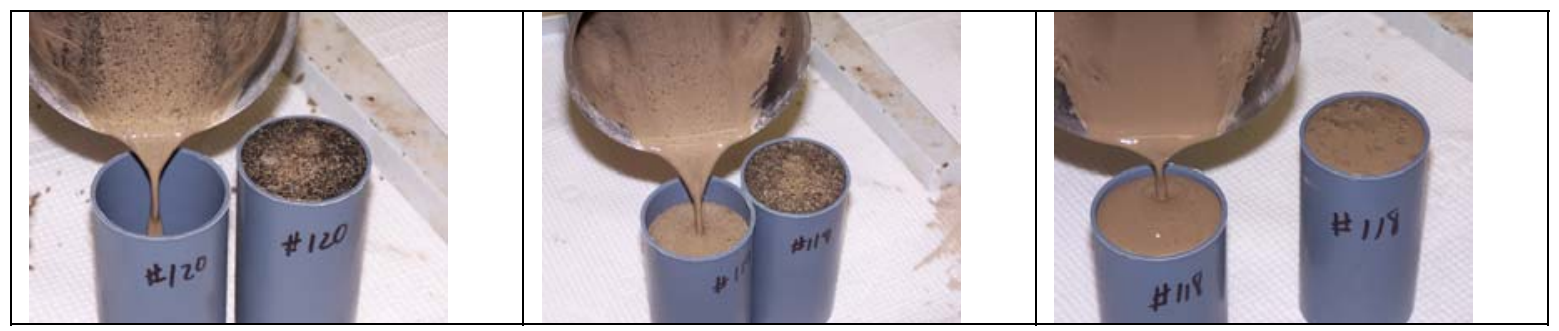

Figure 3-10 Persistence of foam in grout mixes with Q2 during casting. Mixes 120, 119, and 118. 


\subsection{Conclusions}

An evaluation of the WCS1.5 for Tank $50 \mathrm{H}$ and its contents were calculated by influent concentration. At the initiation of tracking Tank $50 \mathrm{H}$ was primarily ETP waste concentrate. The H-Canyon unirradiated fuel campaign added substantial quantities of H-Canyon LAW and nominal quantities of GPE to the tank. The H-Canyon LAW reached a maximum of greater than 36 volume percent in August of 2006. This maximum concentration corresponded to the maximum SPF usage of Daratard 17 and Q2. The increase of DDA processing in December 2007 resulted in a substantial reduction in H-Canyon LAW and a corresponding reduction in admix usage. It can be surmised from this data that the H-Canyon LAW contains constituents that are not in the Saltstone WAC ${ }^{20}$ and are not identified in the Waste Compliance Plan (WCP) ${ }^{1}$ that may contribute to admix demand in the SPF.

The expansion factor and foaminess of CY07 WAC samples, ETP and GPE were evaluated. It was determined that ETP contributed to expansion factor (foam formation) and GPE contributed to foaminess (persistence). It was also ascertained that the undissolved solids stabilized the foam and increased foaminess. This was confirmed with the testing of the supernate form the 2Q07 sample where both the expansion factor and foaminess were less than the as received 2Q07 sample. Q2 additions significantly reduced both the expansion factor and foaminess in all of the samples.

The evaluation of foaming in the grout hopper during the water-to-salt solution transition indicated that evanescent foam in the salt solution is created by mixing. It was determined that the higher W/P during transition produced increased foaming. Additions of Q2 decreased both the volume and persistence of foam.

\subsection{Recommendations}

Based on the testing performed in this study, several recommendations can be made to improve processing at the SPF.

- Track influents as part of WCS 1.5. The method used in this report or a similar method should be used to track the concentration of influents into Tank $50 \mathrm{H}$. The discrepancy between tank reel tape measurements and transfers should be reconciled monthly.

o The benefit of this additional activity is to provide an additional tool to track variables in the Saltstone Facility that may effect operations such as admix demand or other fresh and cured properties.

- In future downstream effects evaluations, evaluate potential influents that are both included in the current WAC and new to Tank $50 \mathrm{H}$.

o The added scrutiny of changes in influents will provide the Saltstone Facility an opportunity to institute or alter WAC limits to ensure safe and consistent operations.

- Perform regular formulation tests with Tank $50 \mathrm{H}$ waste to verify operating parameters and admix needs.

o A regular laboratory check of operating parameters will add assist in correlating lab prepared samples to facility production.

- Evaluate the Saltstone Production Facility operations to determine if increased water to premix during water-to-salt solution transitions is the best practice.

- A review of the rationale for instituting the high water to premix may not still be compelling and the reduced liquid flow to mixer during transition may be beneficial in reducing setbacks. 


\subsection{References}

1. Price, M.R., "Waste Compliance Program for Liquid Waste Transfers from H-Canyon to 241-H Tank Farm," X-WCP-H-00008 Revision 13.

2. Wiggins, A.W., "F/H Effluent Treatment Project Waste Concentrate Regular Waste Compliance Plan (U)," X-WCP-H-00002 Revision 9.

3. Langton, C.A., Hansen, E.K., Burket, P.R., Marsh, D.M., Healy, D.P., "Tank 50 Batch 0 Saltstone Formulation Reconfirmation Using Samples Collected in September 2006 (U)," Savannah River National Laboratory, Aiken, SC, WSRC-TR-2006-00226, (2007).

4. Staub, A.V., "Impact of GPE Evaporator Bottoms on Tank 50," HLW-SSF-TAR-20090002.

5. McLeskey, S.P., "Closure Business Unit Waste Characterization System (WCS) 1.5 Functional Performance Requirements and Design Specification," B-RS-H-00118 Revision 2.

6. Harbour, J.R. and Edwards, T.B., "Grout Variability Study for Projected MCU and DDA Salt Streams," Savannah River National Laboratory.

7. Maxwell, D., "Final Disposition of Phenylborates in Tank 50," CBU-SPT-2003-00105.

8. Vitali, J.R., "Evaporator Performance, Waste Space Management, and Waste Transfers: Fiscal Year 2003 Summary (U)," CBU-SPT-2003-00181.

9. Oji, L.N., McCabe, D.J., "Characterization of Tank 50H Material Per Saltstone Waste Acceptance Criteria Analysis Requirements-2004.," WSRC-TR-2004-00625 Revision 2.

10. Cozzi, A.D., "Properties of Saltstone Prepared Containing H-Canyon Waste," WSRCTR-2005-00149.

11. Langton, C.A., Burket, P.R., Hansen, E.K., Herman, D.T., Marsh, D.M., Snyder, T.K., Wheeler, J.G., "Tank 50 Batch 0 Saltstone Formulation Testing," Savannah River National Laboratory, Aiken, SC, WSRC-TR-2005-00498, (2006).

12. Langton, C.A., Hansen, E.K., Burket, P.R., Marsh, D.M., Healy, D.P., "Tank 50 Batch 0 Saltstone Formulation Confirmation (U)," Savannah River National Laboratory, Aiken, SC, WSRC-TR-2006-00226, (2006).

13. Cozzi, A.D., "Data Package from Vendor for 3QCY08 TCLP Analysis," SRNL-31002009-00022.

14. Reigel, M.M., DiPrete, C.C., Bibler, N.E., "Results for the First Quarter 2009 Tank 50 WAC Slurry Sample: Chemical and Radionuclide Contaminant Results," SRNL-STI2009-00452.

15. Heng, C.J., "Salt Decontamination Demonstration-Technical Summary," DPSP-83-17-17. 
16. Martino, C.J., "Analysis of Tank 49H Samples (HTF-064 - 066) for Saltstone Waste Acceptance Criteria Constituents," WSRC-TR-2005-00336.

17. Hansen, E.K., Cozzi, A.D., "Saltstone Formulation Testing for 4q2007 Start Up," SRNLPSE-2007-00227

18. Cozzi, A.D., Hansen, E.K., "Saltstone Formulation Testing for the Tank 50 Heel, DDA Batch 2," SRNL-PSE-2007-00275.

19. Cozzi, A.D., Hansen, E.K., "Saltstone Formulation Testing for DDA Batch 3," SRNLPSE-2008-00019.

20. Culbertson, B.H., "Waste Acceptance Criteria for the Aqueous Waste Sent to the Z-Area Saltstone Production Facility (U)," Savannah River Site, X-SD-Z-00001.

21. Badheka, N.P., "Characterization of Tank 50H Sample Waste -2007," WSRC-TR-200700253, (2/07).

22. Zeigler, K.E. and Bibler, N.E., "Characterization of Tank 50 Slurry for Saltstone Waste Acceptance Criteria, April 2007 Samples," WSRC-TR-2007-00554, (4/07).

23. Zeigler, K.E., Bibler, N.E., "Results for the Third Quarter 2007 Tank 50H WAC Slurry Sample: Chemical and Radionuclide Contaminant Results," WSRC-TR-2008-0080, $(9 / 07)$.

24. Zeigler, K.E., Bibler, N.E., "Results for the Fourth Quarter 2007 Tank 50H WAC Slurry Sample: Chemical Contaminant Results," WSRC-TR-2008-00013, (11/07).

25. Sethumadhavan, G.N., Nikolov, A.D., Wasan, D.T., "Stability of Liquid Films Containing Monodisperse Colloidal Particles," Journal of Colloid and Interface Science, 240 [1] 105-12 (2000).

26. Bindal, S.K., Sethumadhavan, G., Nikolov, A.D., Wasan, D.T., "Foaming Mechanisms in Surfactant Free Particle Suspensions," AIChE, 48 [10] 2307-14 (2002). 